\title{
PENGARUH SEMANGAT KERJA TERHADAP KEPUASAN KERJA PEGAWAI PADA BAGIAN UMUM SEKRETARIAT DAERAH KABUPATEN LAMPUNG SELATAN
}

\author{
Ani Sriatun ${ }^{(1)}$, Maria Elina $^{(2)}$, Sodirin $^{(3)}$ \\ Fakultas Ekonomi Universitas Sang Bumi Ruwa Jurai \\ ani.sriatun_05@gmail.com,maria.elina@fe.saburai.ac.id,sodirin@fe.saburai.ac.id
}

\begin{abstract}
Abstrak. Bagian Umum Sekretariat Daerah Kabupaten Lampung Selatan merupakan Lembaga yang memberdayakan manusia sebagai Pegawai Negeri Sipil (PNS) ataupun honorer untuk mengelolanya dan dipimpin oleh seorang Sekretariat Daerah. Berdasarkan pengamatan, semangat kerja pegawai masih belum optimal. Pencapaian terpenuhinya kebutuhan pegawai karena adanya semngat kerja bila dirangsang dengan adanya kebijakan yang pada akhirnya merasa puas akan pekerjaan yang diembannya. Tujuan dari penelitian ini adalah untuk mengetahui pengaruh "Semangat Kerja dan Kepuasan Kerja Pegawai Pada Bagian Umum Sekretariat Daerah Kabupaten Lampung Selatan". Hipotesis yang diajukan dalam penelitian ini adalah "Ada pengaruh antara Semangat Kerja dengan Kepuasan Kerja Pegawai pada Bagian Umum Sekretariat Daerah Kabupaten Lampung Selatan". Pengumpulan data penelitian menggunakan teknik populasi penelitian dari 28 responden. Metode penelitian yang digunakan adalah analisis kuantitatif yaitu regresi linier sederhana. Berdasarkan hasil analisis diperoleh persamaan bahwa $\mathrm{Y}=11,146+1,041 \mathrm{X}$. Hasil pengujian menggunakan rumus $t$ student, menunjukkan bahwa thitung 19,245 > taabel 2,70, berarti Ho ditolak dan Ha diterima, dengan demikian hipotesis yang diajukan dapat diterima.
\end{abstract}

Kata kunci: Kebijakan, Kepuasan kerja, Pegawai, Semangat Kerja.

\section{PENDAHULUAN}

Organisasi ditinjau dari sudut pandang kelembagaan merupakan suatu wadah atau tempat manusia dengan keterampilannya melakukan kegiatan dimana didalamnya terpenuhi segala unsur yang mengarahkan dan yang mengayomi pekerjaan mereka. Didalam unsur kelembagaan ini tentu saja dibutuhkan peran dan pengaturan secara manajemen terhadap sumber daya manusia yang ada.

Manajemen sumber daya manusia (MSDM) merupakan satu bidang manajemen yang khusus mempelajari hubungan dan peranan manusia dalam organisasi. Hal ini disebabkan manajemen sumber daya manusia mengatur tenaga kerja yang ada di dalam organisasi, sehingga terwujud tujuan organisasi dan kepuasan kerja pegawai atau karyawan. Manajemen sumber daya manusia juga dapat menghasilkan kinerja yang baik dalam sebuah perusahaan atau lembaga dengan hal ini dapat dilakukan dengan cara penilaian, pemberian balas jasa dalam setiap individu anggota organisasi sesuai dengan kemampuan kerjanya.

Untuk menjamin tercapainya keselarasan tujuan, pimpinan organisasi bisa memberikan perhatian dengan memberikan kompensasi sebagai bentuk pemberi semangat kerja, karena kompensasi merupakan bagian dari hubungan timbal balik antara organisasi dengan sumber daya manusia.

Adapun bentuk kompensasi financial sebagai pendorong semangat kerja dapat digolongkan seperti adanya gaji, tunjangan, bonus (insentif), dan komisi. Sedangkan untuk kompensasi non-financial yang juga sebagai pendorong semangat kerja diantaranya mendapatkan pelatihan, wewenang dan tanggung jawab, 
penghargaan atas kinerja serta lingkungan kerja yang mendukung. Kompensasi sebagai daya dorong semangat kerja adalah segala sesuatu yang diterima para karyawan atau pegawai sebagai balas jasa untuk kerja mereka (Handoko, 2015)

Bagian umum Sekretariat Daerah Kabupaten Lampung Selatan merupakan Lembaga yang memberdayakan manusia sebagai Pegawai Negeri Sipil (PNS) ataupun honorer untuk mengelolanya dan dipimpin oleh seorang Sekretariat Daerah. Berdasarkan pengamatan, semangat kerja pegawai yang salah satunya dapat dijadikan pendorong penyelesaian beban kerja, ternyata masih ada kebijakan yang belum mengarah pada seharusnya, yakni masih adanya kelambanan dalam pemberian kompensasi yang berbentuk kompensasi finansial yang semula bagi para karyawan atau pegawai, dengan adanya kebijakan tersebut harapannya dapat dijadikan sebagai perangsang menyelesaikan beban kerja untuk dan dalam bentuk meningkatkan kinerja.

Pemberian kompensasi ini dapat mempengaruhi semangat kerja karena mereka puas dengan apa yang didapat. Namun kondisinya tidak semua mereka yang terlibat memiliki semangat kerja dan merasa puas dalam bekerja karena ada sesuatu hal yang belum mereka dapatkan, seperti masih rendahnya pemberian kompensasi dalam bentuk insentif finansial selain gaji atau pendapatan lain, sehingga dengan kondisi ini mereka masih merasa kurang puas di dalam mengemban pekerjaan sekalipun mereka ada yang beranggapan bahwa mereka telah bekerja menyelesaikan beban kerja sebagai tugas yang harus dikerjakan, seperti menyelesaikan beban kerja dengan cara lembur.

Semangat kerja juga akan tumbuh bila pihak lembaga memahami secara benar terhadap hal-hal yang dapat meningkatkan gairah kerja, seperti melakukan labour
Turn-Over (perputaran kerja) yang dengan hal ini dapat saja mengurangi kegelisahan atau keluhan dalam bekerja. Dampak dari adanya semangat kerja karena terpenuhinya semua harapan pegawai, maka dipastikan akan berdampak pada kepuasan kerja seperti merasa puas terhadap ganjaran atau kompensasi, puas terhadap jenis kerja masing-masing pegawai, puas terhadap keadilan dan kebersamaan pegawai, Puas terhadap teman kerja karena ada perputaran kerja, menyenangi pekerjaan itu sendiri, puas akan Gaji, bergairah karena ada kesempatan promosi, senang terhadap rekan kerja dan Kondisi kerja .

Berdasarkan faktor dan uraian di atas, maka penulis tertarik untuk menelitinya lebih lanjut dengan judul : "Pengaruh Semangat Kerja terhadap Kepuasan Kerja Pegawai pada Bagian Umum Sekretariat Daerah Kabupaten Lampung Selatan".

\section{KAJIAN TEORI}

\section{Pengertian Semangat Kerja}

Semangat kerja adalah orang yang melakukan pekerjaan secara lebih semangat sehingga pekerjaan akan dapat diharapkan lebih cepat dan lebih baik (Nurmansyah, 2011). Semangat kerja adalah suatu perasaan dari seseorang yang berhubungan dengan jiwa semangat perorangan pada kelompok pekerja yang menunjukkan iklim dan suasana kerja (Anwar, 2002).

Menurut Hasibuan (2004), semangat kerja adalah keinginan dan kesungguhan seseorang mengerjakan pekerjaan dengan baik serta disiplin untuk mencapai produktivitas yang maksimal. Menurut Tohardi (2002), semangat kerja adalah kemampuan sekelompok orang-orang untuk bekerja sama dengan giat dan konsekuen dalam mengejar tujuan bersama.

Menurut Harley (2012) dalam Arwani dan Ashari menyatakan bahwa semangat 
kerja atau moral kerja adalah sikap kesediaan perasaan yang memungkinkan seorang karyawan untuk menghasilkan kerja yang lebih banyak tanpa menambah keletihan yang menyebabkan karyawan dengan antusias ikut serta dalam kegiatankegiatan dan usaha-usaha kelompok sekerjanya dan membuat karyawan tidak mudah terkena pengaruh dari luar, terutama dari orang-orang yang mendasarkan sasaran mereka itu atas tanggapan bahwa satusatunya kepentingan pemimpin perusahaan itu terhadap dirinya untuk memperoleh keuntungan yang sebesar-besarnya darinya dan memberi sedikit mungkin.

\section{Faktor-faktor yang mempengaruhi Semangat Kerja}

Menurut Moekijat (2006), faktor-faktor yang dapat mempengaruhi semangat kerja pegawai adalah :

1. Memberikan kompensasi kepada pegawai secara adil dan wajar.

2. Menciptakan kondisi fisik pekerjaan yang menggairahkan kepada semua pihak.

3. Adanya motivasi dari pimpinan supaya pegawainya mempunyai minat yang besar terhadap pekerjaannya.

4. Pimpinan menempatkan kepentingannya dalam organisasi secara keseluruhan.

5. Memberikan perhatian dan penghargaan kepada pegawai yang berprestasi.

6. Kesempatan bagi pegawai untuk memberikan saran atau aspirasinya pada organisasi.

7. Hubungan yang harmonis antara pegawai dengan pegawai lainnya maupun masyarakat.

\section{Indikator Semangat Kerja}

Menurut Nurmansyah (2011), indikator semangat kerja antara lain :

1. Produktivitas kerja

Salah satu indikasi turunnya semangat kerja ditunjukkan dari turunnya produktivitas kerja, ini dapat terjadi karena karyawan cenderung malas dalam melaksanakan tugas dan sengaja menundanunda pekerjaan dan dapat diukur atau dibandingkan dengan waktu sebelumnya.

\section{Absensi kerja}

Tingkat absensi yang naik juga merupakan indikator turunnya kegairahan kerja, maka perlu dilakukan penelitian bila ada gejala-gejala absensi naik. Pada umumnya bila kegairahan kerja turun, maka pegawai akan malas untuk setiap hari datang bekerja dan setiap ada kesempatan untuk tidak bekerja akan mereka pergunakan, apabila ada waktu luang akan digunakan untuk mendapatkan hasil yang lebih tinggi meskipun ada hal-hal lain.

\section{Labour Turn-Over (perputaran kerja)}

Dalam suatu instansi tidak jarang terjadi perubahan dari sumber daya manusia yang ada, karena ada yang keluar akibat pindah, meninggal, dipecat, pensiun, pengurangan terpaksa, ketidakpuasan mereka bekerja di instansi tersebut. Tingkat keluar masuk yang tinggi selain dapat menurunkan produktivitas kerja juga dapat menghambat kelangsungan hidup instansi.

\section{Kegelisahan / keluhan dalam bekerja.}

Kegelisahan yang timbul dapat berwujud ketidaktenangan dalam bekerja, perasaan tidak aman menghadapi masa depan serta hal-hal lainnya. Kegelisahan pada tingkat terbatas dengan dibiarkan begitu saja pada tingkat tertentu bukanlah tindakkan yang bijaksana karena akan merugikan instansi dengan segala akibatnya. 
5. Tuntutan dalam bekerja.

Tuntutan yang sering terjadi pada instansi merupakan perwujudan dari ketidakpuasan para karyawannya, dimana sering terjadi tuntutan merupakan indikasi yang kuat adanya kegairahan kerja yang menurun dari karyawannya.

\section{Pengertian Kepuasan Kerja}

Kepuasan kerja dapat terasa oleh karena adanya kompensasi. Kompensasi adalah semua pendapatan yang berbentuk uang atau barang langsung atau tidak langsung yang diterima karyawan sebagai imbalan atas jasa yang diberikan kepada perusahaan (Hasibuan, 1990). Kompensasi kerja adalah segala sesuatu yang diterima oleh karyawan sebagai balas jasa untuk kerja mereka (Tohardi, 2002).

Menurut pendapat Siagaan (1992), suatu sistem imbalan yang baik adalah sistem yang mampu menjamin kepuasan para anggota organisasi yang pada gilirannya memungkinkan organisasi memperoleh, memelihara, dan mempekerjakan sejumlah orang yang dengan berbagai sikap dan perilaku positif bekerja dengan produktif bagi kepentingan organisasi.

Kemudian dapat dikatakan, bahwa setiap orang yang bekerja mengharapkan memperoleh kepuasan dari tempatnya bekerja. Pada dasarnya kepuasan kerja merupakan hal yang bersifat individual karena setiap individu akan memiliki tingkat kepuasan yang berbeda-beda sesuai dengan nilai-nilai yang berlaku dalam diri setiap individu. Semakin banyak aspek dalam pekerjaan yang sesuai dengan keinginan individu, maka semakin tinggi tingkat kepuasan yang dirasakan.

Kepuasan kerja adalah sikap umum terhadap pekerjaan seseorang yang menunjukkan perbedaan antara jumlah penghargaan yag diterima pekerja dan jumlah yang mereka yakini seharusnya mereka terima (Robbin, 2016).

Greenberg dan Baron mendeskripsikan kepuasan kerja sebagai sikap positif atau negatif yang dilakukan individu terhadap pekerjaan mereka. Selain itu Gibson (2016) menyatakan kepuasan kerja sebagai sikap yang dimiliki para pekerja tentang pekerjaan mereka. Hal itu merupakan hasil dari persepsi mereka tentang pekerjaan.

\section{METODE PENELITIAN}

\section{Objek Penelitian}

Objek dari penelitian ini adalah aparatur pada Bagian Umum Sekretariat Daerah Kabupaten Lampung Selatan yang beralamat di Jalan Indra Bangsawan, No. 1, Kalianda, Way Urang, Kalianda, Kabupaten Lampung Selatan, Lampung 35551 dimana penelitian ini berlangsung dari bulan Juni hingga Juli 2018.

\section{Metode dan Teknik Pengumpulan Data}

Dalam penelitian ini jenis data yang diperlakukan adalah :

a. Data Primer

Data primer merupakan data dasar yang akan diperoleh langsung tanpa perantara orang atau lembaga lain sebagai pihak ketiga. Data primer ini diperoleh dengan wawancara melalui responden dengan menggunakan daftar pertanyaan.

\section{b. Data Sekunder}

Data skunder merupakan data yang diperoleh melalui orang lain yang berhubungan dengan permasalahan yang dipecahkan. Data sekunder ini diperoleh melalui cara studi dokumenter yaitu mengumpulkan dan mempelajari brosurbrosur serta dokumen organisasi. 


\section{Sampel dan Populasi}

Teknik pengumpulan data dalam penelitian ini menggunakan pengambilan responden secara keseluruhan atau populasi. Menurut Nanang Martono (2011) mendifinisikan populasi adalah seluruh objek atau subjek yang berada pada suatu wilayah dan memenuhi syarat-syarat tertentu berkaitan dengan masalah penelitian, atau keseluruhan unit atau individu dalam ruang lingkup yang akan diteliti. Adapun populasi dalam penelitian ini adalah seluruh pejabat dan staf Pegawai Pada Bagian Umum Sekretariat Daerah Kabupaten Lampung Selatan. Sehingga pada penelitian ini seluruh Pegawai dijadikan responden.

Berdasarkan data yang ada jumlah pegawai adalah 28 orang, kemudian menurut S.Arikunto (2016) apabila objek penelitian lebih dari 100 maka lebih baik diambil sebagian yang besar 15 hingga 20 persen untuk dijadikan sebagai sampel. Menurut data yang ada jumlah populasi dalam penelitian ini berjumlah kurang 28 . Oleh karena jumlah pejabat dan staf Pegawai pada Bagian Umum Sekretariat Daerah Kabupaten Lampung Selatan ini adalah sebanyak 28 orang, maka penulis mengambil seluruhnya untuk dijadikan sampel sebagai responden yaitu 28 orang.

\section{Metode Analisis Data}

Untuk pengolahan data dalam bentuk tabulasi hasil jawaban responden kemudian dilakukan analisis data melalui metode analisis secara kualitatif dan analisa kuantitatif. Analisis kualitatif dilakukan dengan analisis tabel tunggal atau secara parsial yang akan menggambarkan kriteria masing-masing variabel yaitu kreteria variabel Semangat kerja dan Kepuasan Kerja. Analisis kuantitatif yang dilakukan berdasarkan data primer yang diperoleh dari penyebaran instrument (daftar pertanyaan) kepada sampel, dan untuk mengetahui pengaruh dari variabel bebas (independent variable) terhadap variabel terikat (dependent variable).

Persamaan Regresi Linear Sederhana menentukan persamaan regresi linear sederhana untuk X :

$$
Y=a+b X+e
$$

$$
\begin{aligned}
& \text { Keterangan: } \\
& \begin{aligned}
\mathrm{Y} & =\text { Kepuasan kerja } \\
\mathrm{a} & =\text { Konstanta } \\
\mathrm{b} & =\text { Koefisien regresi } \mathrm{X} \\
\mathrm{X} & =\text { Semangat kerja } \\
\mathrm{e} & =\text { Faktor kesalahan }
\end{aligned}
\end{aligned}
$$

Untuk mengetahui besarnya pengaruh, penghitungan koefisien korelasi tersebut kemudian dilanjutkan dengan Rumus Koefisien Determinasi atau Koefisien Penentu (KP):

$$
K P=(r)^{2} x 100 \%
$$

Untuk menguji secara hipotesis secara parsial digunakan Uji t dengan rumus :

$$
t_{\text {hitung }}=\frac{r \sqrt{N-2}}{\sqrt{1-r^{2}}}
$$

Keterangan:

$$
\begin{aligned}
& \mathrm{t}_{\text {hitung }} \quad=\text { Nilai } \mathrm{t} \\
& \mathrm{r}=\text { Koefisien Korelasi } \\
& \mathrm{N} \quad=\text { Jumlah responden } \\
& \text { (Sugiyono, 2008). }
\end{aligned}
$$

Kriteria untuk Uji $\mathrm{t}$ adalah sebagai berikut :

a) Jika $t_{\text {hitung }}>t_{\text {tabel }}$ maka Ha diterima dan Ho ditolak.

b) Jika $\mathrm{t}_{\text {hitung }} \leq \mathrm{t}_{\text {tabel }}$ maka Ha ditolak dan Ho diterima. 
Taraf signifikan dalam penelitian ini digunakan $\alpha=0,05$ atau 5\%. Yang dimaksud dengan Hipotesis nol (Ho) dan Hipotesis alternatif (Ha) adalah :

Ho $=r \leq 0=$ Berarti tidak ada pengaruh semangat kerja terhadap kepuasan kerja $\mathrm{Ha}=\mathrm{r}>0=$ Berarti ada pengaruh semangat kerja terhadap kepuasan kerja.

\section{HASIL DAN PEMBAHASAN}

Variabel penelitian ini terdiri dari satu variabel terikat yaitu Kepuasan Kerja (Y) dan variabel bebas Semangat Kerja (X). Jumlah objek penelitian yang dianalisis sebanyak 28 responden. Dalam instrumen penelitian dalam bentuk kuesioner terdapat lima alternatif jawaban, dan setiap alternatif jawaban tersebut memiliki skor yang berbeda.

\section{Uji Validitas}

Tabel 1. Uji Validitas Semangat Kerja (X)

\begin{tabular}{cccccc}
\hline & $\begin{array}{c}\text { Scale } \\
\text { No } \\
\text { Mean if } \\
\text { Item }\end{array}$ & $\begin{array}{c}\text { Scale } \\
\text { Variance } \\
\text { if Item }\end{array}$ & $\begin{array}{c}\text { Corrected } \\
\text { Item-Total } \\
\text { Deleted }\end{array}$ & $\begin{array}{c}\text { Squared } \\
\text { Deleted } \\
\text { Cultiple }\end{array}$ & $\begin{array}{c}\text { Cronbach's } \\
\text { Alpha if } \\
\text { Item }\end{array}$ \\
\hline X1 & 74.0714 & 26.661 & .759 &. & .634 \\
X2 & 74.0714 & 29.624 & .310 &. & .681 \\
X3 & 74.0714 & 26.513 & .658 &. & .637 \\
X4 & 74.2143 & 27.804 & .616 &. & .652 \\
X5 & 74.1786 & 31.263 & .120 &. & .699 \\
X6 & 74.1786 & 32.004 & .032 &. & .703 \\
X7 & 74.1786 & 33.856 & -.323 &. & .728 \\
X8 & 73.9643 & 29.221 & .346 &. & .677 \\
X9 & 74.1071 & 28.544 & .500 &. & .663 \\
X10 & 73.9643 & 28.999 & .421 &. & .671 \\
Jm1 & 39.0000 & 28.074 & .512 &. & .585 \\
\hline
\end{tabular}

Berdasarkan Tabel 1. dapat diketahui bahwa seluruh item skor pernyataan tentang kepuasan kerja memiliki $\mathrm{r}_{\text {hitung }}$ lebih besar dari 0,5 . Dengan nilai ratarata $r_{\text {hitung }}=0,585$ dan dapat dikatakan bahwa seluruh item pernyataan mengenai kepuasan kerja valid dan dapat digunakan sebagai alat ukur penelitian.
Tabel 2. Uji Validitas Kepuasan Kerja (Y)

\begin{tabular}{|c|c|c|c|c|c|}
\hline No & $\begin{array}{l}\text { Scale } \\
\text { Mean if } \\
\text { Item } \\
\text { Deleted }\end{array}$ & $\begin{array}{l}\text { Scale } \\
\text { Variance } \\
\text { if Item } \\
\text { Deleted }\end{array}$ & $\begin{array}{l}\text { Corrected } \\
\text { Item-Total } \\
\text { Correlation }\end{array}$ & $\begin{array}{l}\text { Squared } \\
\text { Multiple } \\
\text { Correlation }\end{array}$ & $\begin{array}{l}\text { Cronbach's } \\
\text { Alpha if } \\
\text { Item } \\
\text { Deleted }\end{array}$ \\
\hline Y1 & 75.0000 & 31.407 & .758 & . & .656 \\
\hline Y2 & 74.9286 & 35.032 & .288 & . & .701 \\
\hline Y3 & 74.9286 & 31.254 & .654 & . & .660 \\
\hline Y4 & 75.1429 & 32.720 & .605 & . & .673 \\
\hline Y5 & 75.1071 & 35.284 & .250 & . & .704 \\
\hline Y6 & 74.9643 & 34.110 & .524 & . & .687 \\
\hline Y7 & 75.0357 & 40.184 & -.469 & . & .750 \\
\hline Y8 & 74.8571 & 33.090 & .470 & . & .682 \\
\hline Y9 & 75.0000 & 33.852 & .464 & . & .687 \\
\hline Y10 & 74.8571 & 34.275 & .401 & . & .692 \\
\hline $\mathrm{Jml}$ & 39.4643 & 39.369 & .614 & . & .646 \\
\hline
\end{tabular}

Berdasarkan Tabel 2. dapat diketahui bahwa seluruh item skor pernyataan tentang komitmen organisasi memiliki $r_{\text {hitung }}$ lebih besar dari 0,5. Dengan nilai rata-rata $r_{\text {hitung }}=0,646$ dan dapat dikatakan bahwa seluruh item pernyataan mengenai komitmen organisasi valid dan dapat digunakan sebagai alat ukur penelitian.

\section{Uji Reliabilitas Data}

Hasil uji reliabilitas yang didapatkan nilai Alpha Cronbach's semangat kerja (X) sebesar 0,983 dan dapat disimpulkan bahwa kuesioner yang digunakan dalam penelitian ini dinyatakan reliabel karena Alpha Cronbach's sebesar 0,983 > 0,60. Ini berarti bahwa alat ukur yang digunakan dalam penelitian ini sudah memiliki kemampuan untuk memberikan hasil pengukuran yang konsisten dalam mengukur gejala yang sama. Lalu dari hasil uji realibitas nilai Alpha Cronbach's kepuasan Kerja (Y) sebesar 0,710 dan dapat disimpulkan bahwa kuesioner yang digunakan dalam penelitian ini dinyatakan reliabel karena Alpha Cronbach's sebesar 0,710 > 0,60. Ini berarti bahwa alat ukur yang digunakan dalam penelitian ini sudah memiliki kemampuan untuk memberikan hasil pengukuran yang 
konsisten dalam mengukur gejala yang sama.

\section{Analisis Kuantitatif}

Berdasarkan hasil uji t didapat nilai $t_{\text {hitung }}=19,245$. Apabila dibandingkan dengan $t_{\text {tabel }}$ pada taraf signifikan 0,05 yaitu 2,70 , maka $t_{\text {hitung }}=19,245>t_{\text {tabel }} 2,70$ sehingga dapat disimpulkan bahwa hipotesa yang menyatakan terdapat pengaruh antara variabel Semangat Kerja (X) terhadap Kepuasan Kerja Pegawai (Y) pada Bagian Umum Sekda Lampung Selatan terbukti, yakni variabel Semangat Kerja (X) berpengaruh terhadap variabel Kepuasan Kerja pegawai (Y).

Koefisien Determinasi dengan rumus $\mathrm{KD}=\mathrm{R}^{2} \times 100 \%$, maka jabarannya adalah $: \mathrm{R}^{2}=0,967^{2}=0,934=0,934 \times 100=$ $93,4 \%$. Dari perhitungan ini dapat disimpulkan bahwa variabel Semangat Kerja menjelaskan variasi perubahan terhadap variabel Kepuasan Kerja Pegawai pada Bagian Umum Sekda Lampung Selatan sebesar 93,4\%, sedangkan sisanya sebesar $6,6 \%$ dijelaskan oleh faktor lain yang tidak dikaji dalam penelitian ini. Faktor lain yang tidak dijelaskan dalam penelitian ini menurut hemat penulis dapat dipengaruhi oleh Insentif, Lingkungan Kerja, disiplin, motivasi kerja, gaya kepemimpinan dan lainnya.

Persamaan regresi antara variabel Semangat Kerja terhadap Kepuasan Kerja Pegawai adalah $\mathrm{Y}=11,146+1,041 \mathrm{X}$ yang artinya setiap kenaikan satu point daripada variabel Semangat Kerja akan diikuti oleh naiknya variabel Kepuasan Kerja Pegawai pada Bagian Umum Sekda Lampung Selatan sebesar 1,041 point.

Kepuasan Kerja Pegawai Pada Bagian Umum Sekretariat Daerah Kabupaten Lampung Selatan berdasarkan penelitian terdapat sebagian yang kurang puas terhadap ganjaran atau kompensasi yang diberikan Lembaga tempat bekerja, ada juga yang kurang puas terhadap jenis pekerjaan yang menjadi beban kerja. Hanya saja sebagian besar pegawai merasa puas terhadap keadilan dan kebersamaan pegawai dan puas terhadap teman kerja bahkan terhadap, Kesempatan promosi.

\section{KESIMPULAN DAN SARAN}

\section{Kesimpulan}

Berdasarkan analisis data dan pembahasan dapat disimpulkan bahwa hipotesa yang menyatakan terdapat pengaruh antara variabel Semangat Kerja (X) terhadap Kepuasan Kerja Pegawai (Y) pada Bagian Umum Sekda Lampung Selatan terbukti, yakni variabel Semangat Kerja (X) berpengaruh terhadap variabel Kepuasan Kerja pegawai (Y). Dari perhitungan ini dapat disimpulkan bahwa variabel Semangat Kerja menjelaskan variasi perubahan terhadap variabel Kepuasan Kerja Pegawai pada Bagian Umum Sekda Lampung Selatan sebesar $93,4 \%$, sedangkan sisanya sebesar $6,6 \%$ dijelaskan oleh faktor lain yang tidak dikaji dalam penelitian ini. Sedangkan persamaan regresi antara variabel Semangat Kerja terhadap Kepuasan Kerja Pegawai adalah $\mathrm{Y}=11,146+1,041 \mathrm{X}$ yang artinya setiap kenaikan satu point daripada variabel Semangat Kerja akan diikuti oleh naiknya variabel Kepuasan Kerja Pegawai pada Bagian Umum Sekda Lampung Selatan sebesar 1,041 point.

\section{Saran}

Adapun saran yang diajukan peneliti adalah sebagai berikut:

1. Bagi para pegawai pada Bagian Umum Sekda Lampung Selatan, hendaknya semangat kerjanya harus ditingkatkan.

2. Kepuasan kerja pegawai pada Bagian Umum Sekda Lampung Selatan, hendaknya Produktivitas kerja 
ditingkatkan begitu juga dengan perhatian terhadap Absensi kerja, kurangi untuk melakukan Labour Turn-Over (perputaran kerja) dan kurangi kegelisahan / keluhan dalam bekerja dari para pegawai serta hindari adanyan tuntutan dalam bekerja.

\section{DAFTAR PUSTAKA}

Handoko. 2002. Paradigma Baru Manajemen Sumber Daya Manusia(artikel-artikel pilihan). Yogyakarta: Amara Books.

Hasibuan, Malayu SP. 2005. Manajemen Sumber Daya Manusia. Edisi Revisi. Jakarta: PT Bumi Aksara.

Mangkunegara, Anwar Prabu. 2011. Manajemen Sumber Daya Manusia Perusahaan. Bandung: PT. Remaja Rosdakarya.

Nanang Martono, 2011, Metode Analisis Data. Jakarta: Rineka Cipta.

Nurmansyah, Simanjuntak, Payaman J. 2011. Manajemen dan Evaluasi Kinerja. Jakarta: Lembaga Penerbit FE-UI.

Osborn dan Plastrik, Whitmore john. 2002. Performance Coaching. England: John Wiley \& Sons Ltd

Robbins, Stephen P. (2014). Perilaku Organisasi. Edisi kesepuluh. Jakarta: PT.Indeks Kelompok Gramedia

Sudjana. 2015. Metode Statistika. Bandung: Tarsito, cetakan VXII.

Sugiono. 2011. Metode Penelitian Kualitatif, Bandung: Alfabeta

Sugiyono. 2004. Statistik Untuk Penelitian. Cetakan 4. Bandung: Alfabeta.
Taliziduhu, Ndraha. 2015. Teori Budaya Organisasi. Cet.Pertama. Jakarta: PT Rineka Cipta.

Undang-Undang (UU) Nomor 12 tahun 2014 tentang Pemerintahan Daerah. 